\title{
WITH A 'CO-ADJUTOR': COLLABORATION BETWEEN WILLIAM SHAKESPEARE AND JOHN FLETCHER IN THE TWO NOBLE KINSMEN $^{1}$
}

\author{
Com "ajudante": colaboração entre William \\ Shakespeare e John Ffletcher em Os dois primos \\ nobres
}

José Roberto Basto O'Shea*

\begin{abstract}
RESUMO
O presente ensaio visa sintetizar, criticamente, o conhecimento existente acerca da controversa questão da colaboração no contexto teatral elisabetano-jaimesco, em geral, e no caso da composição da peça Os Dois Primos Nobres (1613-1614), especificamente. Recorrendo a seis procedimentos distintos atualmente empregados por especialistas para verificar e aferir autoria e coautoria, o ensaio conclui em favor de inquestionável colaboração entre William Shakespeare, veterano dramaturgo da companhia The King's Men, e John Fletcher, dramaturgo iniciante junto à mesma companhia à época.
\end{abstract}

Palavras-chave: colaboração; coautoria; Shakespeare; Fletcher; Os Dois Primos Nobres.

1 This essay was researched at the Folger Shakespeare Library, in Washington, DC, in 2013, while the author held a short-term Folger fellowship.

* Universidade Federal de Santa Catarina (UFSC). 


\begin{abstract}
This essay attempts critically to synthesize existing knowledge as regards the controversial issue of collaboration in the Elizabethan-Jacobean theatrical context, in general, and in the case of the composition of the play The Two Noble Kinsmen (1613-1614), in particular. Drawing on six different procedures currently applied by specialists to verify and appraise authorship and co-authorship, the essay concludes in favor of unquestionable collaboration between William Shakespeare, senior dramatist of the company The King's Men, and John Fletcher, the same company's junior dramatist at the time.
\end{abstract}

Keywords: collaboration; co-authorship; Shakespeare; Fletcher; The Two Noble Kinsmen.

“(...) five weeks fully penned it, From his own hand, without a co-adjutor, Novice, journeyman or tutor". Jonson, Volpone

\title{
1. INTRODUCTION
}

Notoriously cantankerous, Benjamin Jonson (1572-1637) was probably no easy-going collaborator. To be sure, as collaborator, on two occasions he ended up in jail: in 1597, for his participation in the satiric comedy The Ilse of Dogs, which Thomas Nashe (1567-1601) had begun, and again in 1605 for his involvement in the writing of the city comedy Eastward Hoe! (VICKERS, 2002, p. 25), whose title page of the quarto edition prints Jonson's name next to George Chapman's (1559-1634) and John Marston's (1576-1634). Be that as it may, the fact is that in Elizabethan and Jacobean England collaboration seems to have been so common that, as the epigraph to this essay illustrates, in the Prologue to Volpone (1607) Jonson boasts that he not only wrote the play in record time, but that he did not collaborate.

And the practice of collaboration spans the entire Elizabethan-Jacobean period. After all, Gorboduc (1562), known as the first play in English to use blank verse, ascribes on the title-page of the first quarto shared authorship by Thomas Norton (1532-1584) and Thomas Sackville (1536-1608). And apropos of co-authorship, G. E. Bentley points out that of the 282 plays mentioned in the diary of the contemporary impresario Philip Henslowe (c. 1566-1616), "nearly two-thirds are the work of more than one man" (apud VICKERS, 2002, p. 21). Foregrounding the notion of context, this essay addresses the relevant issues of authorship and collaboration taking into account three main concerns: Shakespeare (1564-1616) and collaboration, 
Shakespeare and Fletcher (1579-1625) as collaborators, and Shakespeare and Fletcher's specific collaboration in the case of The Two Noble Kinsmen.

\section{Shakespeare and Collaboration}

If what is known about the contemporary context of the Elizabethan and Jacobean theater indicates that dramatists seemed to have shared intensely the writing of plays, so much so that roughly half of all Elizabethan and Jacobean plays appear to be collaborations (FREY, 1989, p. 1), and if one of Shakespeare's contemporaries-Thomas Heywood (c. 1573-1641) -claimed to have had a hand, or at least a "main finger", in 220 plays, let me begin by posing a straightforward question: why wouldn't Shakespeare have collaborated? No doubt, like any other dramatist writing at the time, Shakespeare would have regarded co-authorship as a quotidian practice in concocting a play.

Yet, a number of reasons may be marshaled to explain-if not justify--why Shakespeare has often been taken as an exception. For one thing, the importance of Shakespeare's First Folio, a collection of 36 plays edited by his fellow theater professionals John Heminges and Henry Condell and published in 1623, established the image of Shakespeare as the sole author of the plays therein gathered. ${ }^{2}$ Whether consciously or not, it seems that the First Folio editors placed Shakespeare outside the accepted practice of co-authorship in Elizabethan and Jacobean drama. And this image of Shakespeare as sole author persists to the present day and has allowed many scholars to dismiss arguments of co-authorship. In a sense, Heminges and Condell paved the way for the belief that Shakespeare was an exception, the Romantic genius who needed no "co-adjutor" (VICKERS, 2002, p. 8; 18).

However, since the early nineteenth century, scholars have been accumulating evidence that alleges or identifies co-authorship in at least nine surviving plays: The First Part of Henry VI [Thomas Nashe (15671601)]; Edward III; "The Booke of Sir Thomas More" [Anthony Munday (1560?-1633)]; ${ }^{3}$ plus Titus Andronicus [George Peele (1556-1596)]; Timon of Athens and Macbeth [Thomas Middleton (1580-1627)]; Pericles [George Wilkins (1575-1618)], Henry VIII and The Two Noble Kinsmen [John Fletcher

2 The argument that The Two Noble Kinsmen and Pericles were excluded from the First Folio because they were not solely by Shakespeare does not stand. After all, the Folio does include at least other four plays-Titus Andronicus, Timon of Athens, Macbeth, and Henry VIII - that were the result of collaboration

3 These three plays will remain outside the scope of the present essay, as the degree of critical controversy around the very issue of collaboration remains on the level of a quandary, scholarship having yet to produce convincing candidates for Shakespeare's partners (see VICKERS, $2002,145 \mathrm{ff})$. In the case of Edward III, e.g., Wells et al. propose that the play is "of single authorship" $(1987,136)$. 
(1579-1625)]. A tenth play, Cardenio, did not survive, but is believed to have been the outcome of collaboration with John Fletcher.

An intense demand for plays and current publication practices are important aspects of the relevant context. The fact that a large number of Elizabethan and Jacobean plays are either anonymous, wrongly attributed, or thought to be the work of more than one writer results from the context in which early Modern plays were written, acted, and published. The single most important factor in the given context is that early Modern plays were rarely considered "literature" in the sense we understand today. They are better understood as "raw material" for the profitable and prolific entertainment industry of early Modern London, and once plays were bought from writers by acting companies, the writer lost control over them. ${ }^{4}$

Especially in the last decades of the sixteenth and the early decades of the seventeenth centuries, the need of new material to satisfy the demands of both the court and the general public was insatiable. London had a population of around 200,000 people, and around one in ten persons regularly saw (or better, "heard") plays (WELLS, 2006, p. 22). Each professional company performed a different play every weekday afternoon, and evidence from Henslowe's Diary has been used to show that the main companies - the Admiral's Men and the Lord Chamberlain's-needed a new play at least once every two weeks, since one week was considered a long run (POTTER, 1996, p. 23). Brian Vickers submits that the writing process was a speedy one, plays being normally finished in four to six weeks (2002, 43). To be sure, such intense demand favored collaboration as a means of producing acceptable material in as short time as possible, and it has been estimated that almost half of the plays written for the public theatres were of joint-authorship (RASMUSSEN, 2001, p. 82).

As regards publication practices, the company that owned a play had an interest in protecting the investment by not publishing it, as the right to produce a play lay in the ownership of a licensed manuscript copy. Consequently, plays might be in repertory - unpublished-for a considerable time, a period in which they would naturally be adapted for each new production, possibly with additions by different hands (HOPE, 1994, p. 3). When plays were released for publication-often in time of plague, when theaters were closed and companies needed alternative income-the process of transmission produced effects that are relevant to authorship studies. In such process, it is important to recognize that certain aspects of the author's original manuscript—spelling, punctuation, lineation, and even some word 
forms - were not necessarily transmitted faithfully by those who prepared subsequent versions of the text: scribes preparing "fair copies" (transcriptions) to sell to acting companies; bookkeepers producing prompt texts; or compositors setting type either from "foul papers" (handwritten pages) or "fair copies". Any of these individuals may have introduced changes to the original (HOPE, 1994, p. 4).

Hence, the context in which plays were written, staged, and published has crucial consequences for authorship studies. The most challenging conclusion is that our desire to fix single authorship of early Modern playtexts is an anachronism, deriving from a later notion, the aforementioned Romantic myth of the author as solitary genius. But the awareness of context also indicates the need to remain sensitive to the nature of the evidence an early Modern playtext presents. As has been pointed out, it is important to consider which features of a text are stable, and which are not. It is important to know that spelling, punctuation, lineation, as well as contractions, oaths, and stage directions are all subject to change by hands other than the play's "author". And it is also important to know that any play in the repertory of a London company for any length of time might have been cut, revised, or had material added for a tour, or to bring the text up to date, or to suit a particular performance. ${ }^{5}$ Such revisions and interpolations were often done by the company's own playwright, whoever the original author had been (HOPE, 1994, p. 4).

But what does collaboration per se seem to have entailed? Vickers discusses the standard processes of collaboration as they can be reconstructed from the plays themselves (internal evidence) and from documents connected with the stage (external evidence), such as the surviving correspondence between the aforementioned Henslowe and the writers whom he commissioned (2002, p. viii). How exactly did the dramatists divide up the writing, once the plot had been sketched out? One common method was to assign individual acts to one or more writers. In fact the unit of composition (and payment) was often the act. In another procedure, one author created the plot, and another did the actual writing (VICKERS, 2002, p. 27). Since, as Vickers submits, "unity is indeed a rare commodity in co-authored plays" (2002, p. 29), dramatists also seemed to have worked on their own, submitting their scenes to another writer who attempted to supply consistency where it was lacking (POTTER, 1996, p. 24). Hence, writers might specialize in certain kinds of writing - opening scenes, closing scenes, love scenes - and a playtext that was proving problematic might be passed round various authors who would touch it up in the hope of making it successful. 
In the light of what collaboration seems to have entailed, several methods have been deployed for determining authorship and co-authorship, six of which are briefly addressed here. Since the early nineteenth century, such methods have ranged from verse tests and the examination of parallel passages, to the close study of linguistic preferences (including vocabulary and function words), all the way to stylometry, and the verification of socio-historical and sociolinguistic patterns. Vickers starts his survey of the techniques used for identifying co-authors with the oldest method: verse, or metrical tests, a method which is still "being echoed today" (2002, p. 47). The procedure, although initially "subjective"-stemming as it does from the experience of reading or seeing a play and being reminded of some other work--can be formulated and tested objectively, by the application of methods that, in fact, move toward quantification. Elements quantified and compared in verse tests usually comprise feminine endings (unstressed final syllables); placement of caesurae; frequency of end rhymes, line-length variation, and enjambments, as well as the relative presence of prose (VICKERS, 2002, p. 48-56).

The second procedure for determining authorship is the analysis of parallel passages, that is, a passage from a play whose authorship is not questioned placed side by side with a comparable passage from another play, be it anonymous or not. Invoking Muriel Byrne, Vickers stresses that mere parallelism, frequency or clusters of words and images is of small value if not coupled with parallelism of thought $\left(2002\right.$, p. 58) ${ }^{6}$ Other elements that can be paralleled include the use of irony, dramatic situations, characterization, and style. The procedure seems to have been just as often criticized and as it has been used (VICKERS, 2002, p. 60-61).

The third method discussed by Vickers is the large-scale study of a writer's vocabulary. This procedure implies, in particular, verifying the relative frequency and proportion of short, monosyllabic, native (Anglo-Saxon) words vis-à-vis polysyllabic, imported (Latinate) words (2002, p. 75-80). A fourth method, altogether related to the third, has to do with examining linguistic preferences. Consciously or not, writers reveal distinct preferences in the type of diction they use and, once again, in the frequency with which they draw on words. Such preferences can be traced and compared, e.g., a given writer's preference for ye rather than you; hath or doth rather than has or does; or whiles rather than while or whilst. And linguistic preference

6 Synthesizing the work of previous scholars, Kenneth Muir produced a detailed study of image clusters in The Two Noble Kinsmen as compared to clusters found in various other late plays by Shakespeare, namely, Antony and Cleopatra, Coriolanus, The Tempest, Cymbeline, and The Winter's Tale (1960, p. 113-23). 
includes the choice of function words, such as a/an, and, but, by, for, from, in, it, of, that, with (VICKERS, 2002, p. 81-98). As stylistic evidence, function words can be rather revealing. For one thing, as Lois Potter remarks, function words (and contractions) are unlikely to be used or imitated consciously (1996, p. 21).

The fifth method is known as stylometry. The trend of authorship studies in the last half-century has favored computation, elaborate statistical analyses, and high-speed electronic data-processing, and the most prestigious approach to authorship studies nowadays goes by the name of stylometry. Accordingly, also known as the "quantifying approach" (VICKERS, 2002, p. ix), stylometry typically involves computational and statistic quantifying and analysis of texts on the basis of stylistic features, such as average length of word, and the frequency of the appearance as well as the placement of certain words at the start of sentences. Statistical tests can establish general traits of the writer's language that the unaided human eye perhaps cannot discern. However, stylometry has not gone unchallenged. Vickers alerts that if the advantages of such approach are great, "so are the risks" (2002, p. ix), since calculations produced by computers "vary in value according to the intelligence, experience, and perceptiveness of the brains who have devised them" (VICKERS, 2002, p. 99) and, of course, according to the critical acumen of the individual who is applying such materials. Moreover, Jonathan Hope points out that literary scholars and non-statisticians have trouble accepting the results of stylometry because the evidence is often based on apparently arbitrary factors, the object being measured is not always clear, and the conclusions can often seem ciphered (1994, p. 8-9). After all, to run elaborate tests and compile statistical results of the occurrence and placement of a given linguistic feature is not enough; it is crucial to show why something might be relevant, what meaning something might have in terms of a writer's style and collaboration.

The sixth method of co-authorship inquiry draws on socio-historical linguistic evidence. All the methods in attribution studies so far discussed are based on the frequency or the placement of words in a text. Generally, attribution studies have made little use of the history of the language, in particular the notion that language change has a social dimension. However, if we are to resort to socio-linguistic evidence, the key point is that linguistic innovations are mostly made by an educated class, responsive to outside influences and conscious of social and linguistic change (VICKERS, 2002, p. 119).

Yet, the deployment of this method requires attention to a fundamental question: How to analyze linguistic change, in the pursuit of authorship, knowing that such variation may be the result of interference 
by hands other than the original author? Fortunately, as we have seen, there are linguistic variants - such as function words-which are not liable to imitation and whose alternates are not regarded as interchangeable by scribes, bookkeepers, and compositors, and which are therefore textually stable (HOPE, 1994, p. 5). In what has been considered the first study to arouse confidence in socio-historical linguistics as a methodology, ${ }^{7}$ Jonathan Hope applies socio-historical linguistic evidence in comparing and determining linguistic usage of dramatic authors. Hope explains:

[A]t this time [the Renaissance] the English language is changing so rapidly that it is possible to distinguish between the grammatical usages of certain writers, even though they are writing in the same place (London), and at the same time (c. 1590-1625). (1994, p. xv)

Socio-historical linguistic evidence is examined by way of a two-stage, straightforward process. Simply put, in the first stage, the usages of the candidate for co-authorship are established from a sample of their unaided work. In the second stage, usages in the disputed text are compared to those findings to indicate the possibility (or not) of authorship of the suggested candidate (HOPE, 1994, p. 9). ${ }^{8}$ The methodology used by Hope is based on theories developed in the fields of socio-linguistics and socio-historical linguistics by William Labov and Suzanne Romaine. ${ }^{9}$ In general terms, such disciplines have studied linguistic phenomena as affected by class, income, residence, education, and other social markers. Following Romaine's application of the approach to linguistic matter of the past, the basic premise of socio-linguistic evidence is that early Modern English writers will show differences in their usages of certain Modern English variables, according to the influence of factors identified by socio-linguistics as playing as a role in patterning linguistic variation and change: sex, class, and age of users (HOPE, 1994, p. 6; 8). Not surprisingly, urban English, especially in London, was the leader of linguistic change, reflecting awareness about new fashions, foreign linguistic imports, technical jargon, etc. In the intensely language conscious 1590 s, any deviation from the norm could soon be represented on stage (VICKERS, 2002, p. 120).

The socio-historical approach takes into account the profile a given writer. For instance, Fletcher was born in 1579 in the southeast of England

$7 \quad$ See Brian Vickers (2002, p. 121).

8 Two provisos are in order. First, as we have seen, given the importance of collaboration in the contemporary context, the very notion of an "unaided" text is problematic; second, it becomes evident that the application of the procedure depends on the existence of a suitable corpus of non-controversial texts.

9 Hope cites Labov's classic Sociolinguistic Patterns (1972) and Romaine's Socio-Historical Linguistics (1982). 
and brought up in an upper-class, urban environment, belonging as he did to a distinguished ecclesiastic and literary family. His father became bishop of London in 1594, but the family probably resided in the capital since 1589 . The evidence favors the view that Fletcher attended Cambridge University. This profile establishes a sharp contrast with Shakespeare, who was born fifteen years earlier, in the rural southwest midlands, in a middle-class family, and lacking in higher education.

It can be assumed that younger, higher-class, more educated, more urban individuals will be at the forefront of linguistic change (HOPE, 1994, p. 11). Thus, according to sociolinguistic premises, Fletcher would use more in-coming prestige variants than Shakespeare (HOPE, 1994, p. 8). As instances of linguistic change suitable as socio-historical linguistic evidence, Fletcher shows a more highly unregulated usage of the auxiliary "do" than Shakespeare (HOPE, 1994, p. 11-26); a more highly unregulated distinction between relative clause markers, such as "who" and "which", on the basis of the antecedent, "who" for personal antecedents, "which" for non-personal (HOPE, 1994, p. 28-30); and a more conspicuous replacement of "thou" by "you" in the singular (HOPE, 1994, p. 54). These are believed to have been the rising variants that would eventually become standard. Given the maxims of sociolinguistics, we can perhaps agree with Hope that Shakespeare's rural upbringing makes him a rather regulated writer, while Fletcher's more urban birth and childhood push him toward innovation (1994, p. 20). As regards linguistic change, Vickers goes so far as to propose that Shakespeare might have struck his contemporaries as old-fashioned (2002, p. 121).

One of the advantages of the socio-historical linguistic method is that its basis can be accessible to anyone familiar with the language or literature of the period: no statistical background in required (HOPE, 1994, p. xv). In other words, the differences detected by the method between the linguistic usage of authors are explicable, and such explanation does not depend on complex statistical tests for validation (HOPE, 1994, p. 9).

\section{Shakespeare And Fletcher}

As an aspiring dramatist rising in the ranks of Shakespeare's own company, Fletcher engages directly with Shakespeare in the only dramatic sequel to any of the latter's plays written before the Restoration: The Woman's Prize, or The Tamer Tamed (c. 1611). Stanley Wells observes that it was a daring move, on the part of the young dramatist, to take on his senior. After all, the sequel, in which Kate is now dead and Petruccio has remarried, is an intriguing intervention in the sexual politics of the age, revising the place of women in society from that offered by The Taming of the Shrew some twenty years earlier (2006, p. 203; 205). 
With Francis Beaumont (1584-1616), his first collaborator, Fletcher had already written highly successful plays, such as Philaster (c. 1609), The Maid's Tragedy (c. 1609), and A King and No King (1611). ${ }^{10}$ As early as 1901, scholars were pointing out that by the time Shakespeare and Fletcher worked together in Cardenio, Henry VIII, and The Two Noble Kinsmen, Fletcher was "one of the most prominent dramatists (...) of the younger generation" (THORNDIKE, 1966, p. 35). As we have seen, Fletcher belonged to a privileged social class, one that frequented not only the public but the more exclusive indoor theaters in London, and he was also a leading figure in the evolution of the tragicomedy. ${ }^{11}$

In 1612-13, the King's Men twice presented at court a play titled "Cardenna" or "Cardenno", which survived only in a thoroughly rewritten version dating from 1727-28. With a title deriving from the character Cardenio, in the first part of Cervantes' Don Quixote (which had appeared in Thomas Shelton's English translation in 1612), a play called "The History of Cardenio", by Fletcher and Shakespeare, appears in 1653 in the Stationers' Register (a record kept by the Stationers' Company, an association of printers who licensed publishing). In 1727, Lewis Theobald presented at Drury Lane a play with the title Double Falsehood; or, The Distrest Lovers. In the year following its first performance, Theobald published Double Falsehood as "Written Originally by W. SHAKESPEARE; And now Revised and Adapted to the Stage By Mr. THEOBALD" (apud HOPE, 1994, p. 90).

The authorship of Henry VIII was not called into question until the mid-nineteenth century, when S. Hickson (1850) and J. Spedding (1850), working independently, published articles that suggested that the play was a collaboration between Shakespeare and Fletcher, the younger playwright who eventually succeeded Shakespeare as dramatist to the King's Men theater company. The debate around the co-authorship of $H 8$ has been intense, but nowadays the collaboration has been amply documented and is practically a critical consensus. ${ }^{12}$

10 In 1679, The Two Noble Kinsmen was included in Beaumont and Fletcher's Folio, Fifty Comedies and Tragedies. Written by Francis Beaumont and John Fletcher etc. Interestingly, the attribution was current not only in the Anglophone world, as a French translation by Ernest Lafond, for instance, published in Paris in 1865, attributes the play to the famous Beaumont-Fletcher tandem (see References).

11 In the address "To the Reader", prefacing the text of his play The Faithful Shepherdess, Fletcher (1980) offers a fascinating definition of tragicomedy that has become classic: "A tragie-comedie is not so called in respect of mirth and killing, but in respect it wants deaths, which is inough to make it no tregedie, yet brings some neere it, which is inough to make it no comedie: which must be a representation of familiar people, with such kind of trouble as no life be questioned [i.e., with problems that are not life-threatening]" (p. 15-16).

12 See, especially, Vickers (2002, p. 333-402), and also Wells (2006, p. 194; 217-23). 


\section{Shakespeare, Fletcher and The Two Noble KINSMEN}

The date of composition of The Two Noble Kinsmen is generally agreed to be 1613-1614, when Fletcher was 33 and Shakespeare 48. Systematic attempts to ascribe The Two Noble Kinsmen to Shakespeare and Fletcher go back at least to W. Spalding's A Letter on Shakespeare's Authorship of The Two Noble Kinsmen. Writing in 1833, evidently a time when the play remained "excluded from the received list of Shakespeare's works", Spalding undergoes indefatigable analysis and is sure that the collaboration is "rightly... attributed" (1876, p. 2). In the middle of the nineteenth century, when Charles Knight included it in his Pictorial Edition (1839-1841), The Two Noble Kinsmen made an isolated appearance in a collected edition of Shakespeare, albeit among the "Doubtful Plays" (WAITH, 1989, p. 7).

We cannot know the details, discussions, general ideas or ground plan as regards Shakespeare and Fletcher's collaboration in The Two Noble Kinsmen (MEHL, 2010, p. 287), but presumably the two authors would have discussed the overall design of the play in relation to its principal, acknowledged, source, Geoffrey Chaucer's The Knight's Tale (WELLS, 2006, p. 27). ${ }^{13}$ Be that as it may, in the case of Kinsmen, argumentation about co-authorship has been based both on external and internal evidence.

External evidence that Shakespeare had worked with a co-author is based on two documents. The first document mentioning the play, the entry in the Stationers' Register for 8 April 1634, announces "a TragiComedy called the two noble kinsmen by John ffletcher and William Shakespeare" (apud VICKERS, 2002, p. 402). And the quarto edition, published later that same year, reaffirms the collaboration: "(...) written by the memorable Worthies of their time; Mr. John Fletcher, and Mr. William Shakespeare" (Facsimile), noticeably foregrounding Fletcher's name. ${ }^{14}$

Given the relative scantiness of external evidence, most authorship studies of The Two Noble Kinsmen have been largely based on internal evidence. A sense that there are two distinct styles in the play goes back at least to the first half of the nineteenth century, as evidenced in Specimens of English Dramatic Poets Who Lived about the Time of Shakespeare (1808), by Charles Lamb (1775-1834). Both Shakespeare and Fletcher seem attracted

13 At any rate, Mark Dominik (1988) concludes his book on Shakespeare-Middleton collaborations affirming that "intimate collaboration seems to be the usual way in which Shakespeare collaborated". And he adds: "in plays like Pericles and The Two Noble Kinsmen, the sections that are often considered non-Shakespearean are in reality mixed texts, with Shakespearean and non-Shakespearean contributions intermingled" (p. 110).

14 Lois Potter comments that Fletcher's name appearing first on the title page may mean only that the publisher was observing alphabetical order, even though, in her opinion, the play "belongs slightly more" to Fletcher than to Shakespeare (1996, p. 6). 
to the moral and dramatic dilemmas imposed by the story's action, and they may have worked out a coherent story line. However, in terms of method and characterization the difference between their concerns turns out to be as clearly marked as that between their verse styles (VICKERS, 2002, p. 496).

Structurally, the sequence of episodes is skillful, and the following is the main division of the play, established by a fairly large measurement of critical consensus:

- Shakespeare: Act 1; Act 2.1; Act 3.1-2; Act 4.3; Act 5.1, 3-4;

- Fletcher: Prologue; Act 2.2-6; Act 3.3-6; Act 4.1-2; Act 5.2; Epilogue $^{15}$

This division indicates that the work of the two playwrights is tightly interlaced.

According to Vickers, Shakespeare is responsible for the exposition in the main plot (the kinsmen and the conflict between love and friendship), writing Act 1 and beginning the subplot (the Jailer's daughter) in Act 2, scene 1. Here, the Jailer, his Daughter, and her Wooer constitute the most original contribution to the play's structure, having no basis at all in Chaucer's "The Knight's Tale", in which Palamon's escape from prison, after seven years, depends on the help of a "freend".

It is true that after more than a century of investigation the precise "seams" between Shakespeare's and Fletcher's work remain controversial (FREY, 1989, p. 31). Yet, drawing on previous, extensive observation with Timon, Pericles, and Henry VIII, Vickers argues that it is precisely at the "transition points", where the co-author takes over, that we can notice the presence of a second set of hands (2002, p. 493). In fact, at a few points, the playwrights seem not to have fully co-ordinated their thinking. It appears that Shakespeare and Fletcher did not entirely agree, for example, as regards dramatic method and character.

Fletcher's preferred method is to confront characters with an agonizing dilemma, aiming at "sensational dramatic novelty". Theseus's verdict of death for the loser in the combat between the two kinsmen-an element not found in Chaucer's story-would be a typical "Fletcherian twist" (MEHL, 2010, p. 283-84). Whereas Shakespeare seems more concerned with long-term processes, dramatic coherence, and (possible) unity, Fletcher is more interested in the events of the moment, in surprising developments or reversals that could keep the audience stimulated (VICKERS, 2002, p. 494).

15 See Waith (1989, p. 22); Montgomery and Taylor cast some doubt over the Prologue, the Epilogue, and 1.4, 1.5, 3.2, and $4.2(1989$, p. 625). And the Morris dance in 3.5 is believed to have been borrowed from Beaumont's Inner Temple and Gray Inn's Masque (Wells et al., 1997, p. 134). 
Characterization also reveals a certain degree of discord. The transformation of Palamon and Arcite in Act 2 is readily noticeable. At the opening of Act 1, scene 2 (Shakespeare's), in the introduction of the main plot, the kinsmen are presented as stoic, condemning the moral laxity of their own Thebes, and its tyrant (Creon) in energetic verse. Shakespeare advances moral values, by way of the disgust that Arcite expresses for his own city,

Thebes, and the temptings in't...

where every evil

Hath a good colour; where every seeming good's

A certain evil (1.2.4, 42-44),

and denounces tyranny, by way of Palamon's censure of their uncle Creon as

A most unbounded tyrant, whose successes

Makes heaven unfeared and villainy assured

Beyond its power there's nothing (1.2.71-73). ${ }^{16}$

However, Fletcher allows the two heroes to indulge their grief in plangent lines. In Act 2, scene 2 (Fletcher's), they speak of the same Thebes with a nostalgia that seems at odds with their former condemnation (WELLS, 2006, p. 218). Taking up the story of the imprisoned heroes, Fletcher presents them with a behavior that is anything but stoic. This Palamon, unlike the Palamon who, with Arcite, detested the corrupt city, now delivers ubi sunt lines of lamentation:

Where is Thebes now? Where is our noble country?

Where are our friends and kindreds? Never more

Must we behold those comforts (...) (2.2.10-13).

Therefore, in Act 2, instead of being the disillusioned social critics, the two kinsmen appear as nostalgic, sentimental figures who seem never to have been concerned with social questions. Thebes, no longer decadent, is described as noble.

Emilia, as treated by the two co-authors, might be a character from two different plays (VICKERS, 2002, p. X). Shakespeare emphasizes her chastity, her maidenly lack of interest in men, and her nostalgic memory of her girlhood friendship with Flavina (see quote below). When Fletcher brings her on stage for the cousins' contemplation, she reveals quite a different set of values. Examining the flowers in the garden outside the prison, Emilia comments on the narcissus: 
That was a fair boy certain, but a fool

To love himself. Were there not maids enough? $(2.2 .136-37)$

Such an amorous concern is a far cry from Shakespeare's chaste presentation of the character. However, we are reminded, inconsistencies in characterization and method do not refute co-authorship; conversely, they imply the presence of "different hands". Furthermore, the two authors could be writing separately, unaware of how each had handled Emilia (or the kinsmen) (MONTGOMERY; TAYLOR, 1987, p. 626).

Joint authorship is more evident in verbal (and verse) style than in the handling of method or characterization, and, accordingly, most identifications based on stylistic evidence start from the perception of the already mentioned two distinct poetic styles in the play. Granting that suitable comparison samples cannot always be compiled, and that socio-historical linguistic evidence cannot offer a categorically positive attribution, Hope concludes, however, that "marked differences in linguistic usage between Shakespeare and Fletcher allow detailed comments on the likely authorship of individual scenes to be made" (1994, p. 149). In fact, by way of vocabulary tests, certain linguistic preferences have been identified. Fletcher's "urban", "modern" fondness for has in place of hath, you in place of ye, and for the contraction 'em in place of them, for example, has long been noticed. And the second act, after the first scene, i.e., the moment of "transition" discussed above, and most of the following two acts are written in a noticeably different idiom (MEHL, 2010, p. 282).

The verse styles in the play are also discrepant. Comparing and contrasting Shakespeare's and Fletcher's versification, Spalding concludes that Shakespeare's versification is broken and full of pauses, he avoids feminine endings, and is prone to round up speeches or scenes with hemistiches. Fletcher's rhythm is smoother, he often keeps the lines distinct and without breaks, abounding in feminine endings, and seldom leaves a line incomplete at the end of a verse (SPALDING, 1876, p. 11;32;36-8; 47). Writing in the beginning of the nineteenth century, Lamb produced a classic description of the difference between Fletcher's and Shakespeare's verse styles (relating especially to Shakespeare's late plays). Fletcher, Lamb writes,

lays line upon line, making up one after another, adding image to image so deliberately that we see where they join. Shakespeare mingles everything, embarrasses sentences and metaphors; before one idea has burst its shell, another is hatched and clamours for disclosure. (apud Bate, 1992, p. 556) 
The complexity of Shakespeare's verse style is evident in a passage often quoted: Emilia's description of her childhood friendship with Flavina, who died_or as Shakespeare/Emilia puts it— “took leave o'th'moon”-when they were only 11 years old:

What she liked

Was then of me approved, what not, condemned, No more arraignment. The flower that I would pluck And put between my breasts- $\mathrm{O}$, then but beginning To swell about the blossom-she would long Till she had such another, and commit it To the like innocent cradle, where, Phoenix-like, They died in perfume. On my head no toy But was her pattern; her affections-pretty, Though happily hers careless were-I followed For my most serious decking. Had mine ear Stol'n some new air, or at adventure hummed one From musical coinage, why, it was a note Whereupon her spirits would sojourn-rather, dwell on-And sing it in her slumbers. This rehearsal-Which fury-innocent wots well comes in Like old importment's bastard-has this end, That the true love 'tween maid and maid may be More than in sex individual. (1.3.74-93)

This is Shakespeare at his most complex and convoluted, wresting vocabulary and syntax to new linguistic ends (WELLS, 2006, p. 220).

By contrast, the opening dialogue of Palamon and Arcite in prison (2.2) bears the aforementioned "indubitable marks" of Fletcher's relative simplicity:

\section{PALAMON}

How do you, noble cousin?

ARCITE

\section{PALAMON}

How do you, Sir?

Why, strong enough to laugh at misery

And bear the chance of war; yet we are prisoners

I fear forever, cousin.

ARCITE

And to that destiny have patiently

I believe it,

Laid up my hour to come.

\section{Conclusion}

Dramatic texts are inherently collaborative, and, in the case of The Two Noble Kinsmen, even if we have to admit that we cannot know for sure who wrote each and every word, the collaboration seems irrefutable. 
Stanley Wells goes so far as to affirm that in the last active year of his career (1613), Shakespeare worked only in collaboration (2006, p. 209). And after discussing in minute detail five plays that Shakespeare has co-authored, Brian Vickers concludes, strikingly, that recent, sophisticated approaches have only confirmed authorship divisions originally made with basis on stylistic evidence supplemented by verse tests carried out more than a century ago (2002, p. 146).

Taking into account the contemporary context, which in so many ways favored collaboration, examining various studies that have been carried out by specialists, whether by way of literary, statistical or sociolinguistic procedures, and putting aside Romantic preconceptions of the solitary genius and the bardolatry that still encumber us, we can see clear evidence that Shakespeare did indeed collaborate with a variety of co-writers, e.g., George Peele, Thomas Middleton, George Wilkins, and, of course, John Fletcher. And such collaboration, far from diminishing Shakespeare's own work, renders it altogether more complex and fascinating.

As regards The Two Noble Kinsmen, specifically, although the collaborators at times seem to see different sorts of potential in their material and, occasionally, their divergent methods and perspectives have resulted in inconsistencies, the overall closeness and efficiency of the characterization is surprising (WAITH, 1989, p. 63). Besides, as we have seen, these very inconsistencies have been pointed out as evidence of more than one set of hands. Given the division of scenes, Shakespeare, the senior partner, writing the entire first act and the first scene of the second, introduced both the plot and the subplot. Moreover, he writes some scenes of both plots in Acts 3 and 4, and all the scenes of the main plot in the last act. The fact that Shakespeare wrote the exposition and the conclusion backs up the supposition that he had the overall vision of the work. After a carefully illustrated analysis of "contingencies", Lois Potter concludes that the two dramatists wrote concurrently, but that Fletcher constructed the final draft $(1996$, p. 32). Writing in the reliable Textual Companion to the Oxford Compact Edition, Wells et al. conclude that the studies of the internal evidence corroborate the external evidence, and discern two stylistic patterns in the play, one congruent with late Shakespeare, the other equally congruent with middle Fletcher (1987, p. 134). It is small wonder that three editions of The Two Noble Kinsmen recently published-E. M. Waith's for the Oxford Series (1989), Lois Potter's for the Third Arden (1997), and Barbara Mowat and Paul Werstine for the Folger Library (2010)-accept the co-authorship and print the two authors' names on the cover. Echoing the frontispiece of the play's very first publication, i.e., the 1634 Quarto, that is precisely where both names belong. And if in the Prologue to Volpone Ben Jonson had to make the point that the play was written solo, Shakespeare, in The Two Noble Kinsmen, could never do likewise. 


\section{REFERENCES}

BATE, Jonathan. The Romantics on Shakespeare. Harmondsworth: Penguin, 1992.

DOMINIK, Mark. Shakespeare-Middleton Collaborations. Beaverton, OR.: Alioth Press, 1988.

ERNE, Lukas. Shakespeare as Literary Dramatist. Cambridge: Cambridge UP, 2003.

FLETCHER, John. The Faithful Shepherdess. A Critical Edition. Ed. Florence Ada Kirk. New York: Garland Publishing, 1980.

FREY, Charles H., ed. Shakespeare, Fletcher and The Two Noble Kinsmen. Columbia: University of Missouri Press, 1989.

. Collaborating with Shakespeare: After the Final Play. Shakespeare, Fletcher and The Two Noble Kinsmen. Ed. Charles Frey. Columbia: University of Missouri Press, 1989. p. 31-44.

HOPE, Jonathan. Authorship of Shakespeare's Plays: A Socio-linguistic Study. Cambridge; New York: Cambridge University Press, 1994.

JONSON, Ben. Volpone. Second Edition. Ed. Robert N. Watson. New Mermaids. London; New York: W. W. Norton, 2003.

LAMB, Charles. The Works of Charles and Mary Lamb. 7 vols. Ed. E. V. Lucas. London: 1904.

MEHL, Dieter. The Two Noble Kinsmen: A Modern Perspective. In: MOWAT, B. A.; WERSTINE, P. (Eds.). The Two Noble Kinsmen. Folger Shakespeare Library. New York: Simon \& Schuster, 2010. p. 273-91.

MONTGOMERY, W.; TAYLOR, G. The Two Noble Kinsmen. In: WELLS, S.; TAYLOR, G.; JOWETT, J.; MONTGOMERY, W. (Eds.) William Shakespeare: a Textual Companion. Oxford: Clarendon Press, 1987. p. 625-36.

MUIR, Kenneth. Shakespeare as Collaborator. London: Methuen, 1960.

POTTER, Lois. Introduction. In: SHAKESPEARE, W.; FLETCHER, J. The Two Noble Kinsmen. Arden Third Series. Ed. Lois Potter. London: Thomson Learning, 1996.

RASMUSSEN, Eric. Collaboration. In: DOBSON, M.; WELLS, S. (Eds.). The Oxford Companion to Shakespeare. Oxford: Oxford University Press, 2001. p. 80-82.

SHAKESPEARE, William. Two Noble Kinsmen. Old English Drama. Students' Facsimile Edition. Folger Shakespeare Library. Reprint of the 1634 Quarto.

SHAKESPEARE, William; Fletcher, J. The Two Noble Kinsmen. Oxford World's Classics. Ed. Eugene M. Waith. Oxford: Oxford University Press, 1989.

SPALDING, William. A Letter on Shakespeare's Authorship of The Two Noble Kinsmen (1833). London: Trübner \& Co., 1876.

THORNDIKE, A. H. The Influence of Beaumont and Fletcher on Shakespeare (1901). New York: AMS Press, 1966.

VICKERS, Brian. Shakespeare, Co-author: A Historical Study of Five Collaborative Plays. Oxford; New York: Oxford University Press, 2002.

WAITH, Eugene M. Introduction. The Two Noble Kinsmen. In: SHAKESPEARE, W.; FLETCHER, J. Oxford World's Classics. Ed. Eugene M. Waith. Oxford: Oxford University Press, 1989. p.1-66.

WELLS, Stanley. Shakespeare and Co. Christopher Marlowe, Thomas Dekker, Ben Jonson, Thomas Middleton, John Fletcher and Other Players in His Story. London; New York: Allen Lane, 2006.

WELLS, STANLEY; TAYLOR, G.; JOWETT, F; MONTGOMERY, W. (Eds). William Shakespeare: A Textual Companion. Oxford: Clarendon Press, 1987.

Submetido em: 11/03/2015

Aceito em: 17/10/2015

Revista Letras, Curitiba, n. 92 p. 49-65, JUL/DEZ. 2015.

ISSN 2236-0999 (VERSÃo ELETRÔNICA) 